\title{
WHAT IS WRONG WITH THE QUALITY OF HOTEL SERVICE? THE CRITICAL ROLE OF WORK-FAMILY CONFLICT AND ITS NEGATIVE OUTCOMES
}

\author{
Aleksandra Grobelna*
}

\begin{abstract}
Background. Hospitality jobs are characterised by long, unsocial working hours, irregular and inflexible work schedules, limited time off, shift work, etc. All these aspects, including changes in customers' needs, create a stressful workplace, where increased demands require more time and energy from employees that "must be" devoted to work related activities instead of family life. Thus, unsurprisingly, hotel employees who try to deliver excellent service and meet high quality standards may be particularly prone to experience work-family conflict, which in turn may lead to very adverse effect for customer service and, as a result, many negative outcomes.
\end{abstract}

Research aims. The aim of the study is to investigate the relationship between work-family conflict and its critical consequences for customer service. The research problem is to find an answer to the questions: 1 . is there a relationship between work-family conflict and employees' depersonalisation, which is displayed by treating others (hotel guests) as objects rather that people, through cynical and uncaring attitudes, and 2. may employees' depersonalisation significantly decrease employees' customer orientation and the extra-role customer service.

Methodology. The survey instrument was used to collect information from eight hotels in the Pomerania Province (Northern Poland). A total of 130 hotel employees agreed to participate in the study.

Key findings. The study results showed that employees who experience high work-family conflict are also more likely to be detached and emotionally callous towards hotel guests, as a result demonstrating lower customer orientation and decreased extra-role service.

Keywords: hotel employees, work-family conflict, depersonalisation, customer orientation, extra-role customer service.

\footnotetext{
”Gdynia Maritime University. E-mail: aleksandra.grobelna@wpit.umg.edu.pl
} 


\section{INTRODUCTION}

In a highly competitive market situation, the success of a hospitality business strongly depends on its employees' delivering high quality service (Pan, 2018). Frontline employees are perceived as company representatives genuinely interacting with customers (Wang et al., 2017). Those interactions influence service quality (Chu et al., 2012) and have a great impact on customer satisfaction (Alhelalat et al., 2017). Thus, employees' performance and its quality primarily determine the success or failure of a hotel business (Cheng, 2011).

However, although they play a key role in offering good hosting experience (Lashley, 2008), frontline employees have to deal with various work-related stressors (Lin et al., 2013) that can contribute to problems in successful balancing their work and non-work domains of life. It is well established in extensive literature that hospitality employees experience irregular and inflexible work schedules, heavy workloads, low wages, limited time off, demanding and difficult customers and other excessive job demands (Gamor et al., 2014; Karatepe, 2011; Mansour \& Tremblay, 2016; McNamara et al., 2011; Mulvaney et al., 2007; Qu \& Zhao, 2012; Wong \& Ko, 2009). Specifically, given the fact that a hospitality business is opened 365 days a year, 24/7 (Mulvaney et al., 2007; Walker, 2014), employees' work schedules may differ from a common "Monday-to-Friday schedule" (Lin et al., 2013, p. 178). Generally, they stay at work much longer than persons employed in other industries (Walker, 2014) and during periods that are usually off work for other people, such as weekends and holidays (Gamor et al., 2014).

Additionally, employees, especially those developing their careers, work particularly hard, even up to ten hours a day (Walker, 2014). It is also well known that they have to "pay their dues" if they want to go ahead (Xiao \& O'Neill, 2010, p. 421), thus they may be less likely to leave work earlier or take a short break for family issues (Mulvaney et al., 2007).

Moreover, employees in frontline service positions also face roundthe-clock customer contact (Kim et al., 2007), during which customers may observe every detail of service provision (Redman \& Mathews, 1998), which can be particularly stressful, especially that guests change (Gamor et al., 2014), and each of them may have their own requirements (Walker, 2014). In such a demanding work environment, 
ensuring guest satisfaction may result in employees' devotion to their work (Pan, 2018) that may generate problems in balancing work and family responsibilities well, as dedicated employees often work overtime and make additional effort to solve customers' problems effectively (Karatepe \& Baddar, 2006). Furthermore, frontline hotel employees often face demanding, difficult and aggressive customers who are highly emotional and display dysfunctional behaviours (Karatepe \& Kilic, 2007; Wong \& Ko, 2009; Poulston, 2009). Interpersonal relations with such hotel guests can be particularly emotionally charged, depleting employees' energy and making it difficult "to leave work at work" and "not bring it" home, especially by those frontline employees, who poorly cope with their emotional stress triggered by customers' misbehaviour (Choi et al., 2014).

Finally, in addition to the above work characteristics, high employee turnover is also a critical issue in the labour intensive hospitality industry (e.g. Grobelna et al., 2016; Karatepe, 2009; Mansour \& Tremblay, 2016; Lee \& Way 2010). Employees who stay in their positions can be heavily loaded (Faulkner \& Patiar, 1997) and required to devote much more of their time, talent, and energy to fulfil their excessive duties.

Given high demands of hospitality jobs and the fact that hotel employees only spend a certain number of hours a day at work and their energy level is expendable (Byrne \& Canato, 2017), it is not surprising that they have limited resources (i.e. time and energy) within which they can involve in personal and family activities, thus experiencing difficulties in managing their work and family roles successfully (Karatepe, 2011). Therefore, the work-family conflict (WFC) is naturally perceived as one of the common work stressors that hospitality employees are confronted with (Qu \& Zhao, 2012; Karatepe \& Karadas, 2014). In such a work context, investigating the phenomena of WFC seems critical, especially that addressing this issue has a potential to improve performance and maintain high quality service, also enhancing a company's strategic competitive advantage (Mulvaney et al., 2007).

However, although work-family conflict is crucial to hotel employees (Pan, 2018), empirical studies on this issue in the hospitality context are scarce (Mulvaney et al., 2007), including latest hospitality research, where it still remains an understudied area (Dai et al., 2016; Pan, 2018). Specifically, so far, few studies have investigated the effects of work-family conflict on employee outcomes in hospitality (Karatepe \& 
Kilic, 2007; Karatepe, 2008); moreover, those conducted have produced inconsistent results (Karatepe \& Kilic, 2007). Thus, studies particularly relating to the outcomes of work-family conflict actually seem to be a core in the field of hospitality management.

Based on the above and answering the literature calls, the aim of this study is to investigate the relationship between the work-family conflict and its critical consequences for customer service. The research problem is seeking the answer the following questions: 1 . is there a relationship between work-family conflict and employees' depersonalisation which is displayed by treating others (hotel guests) as objects rather that subjects; and 2. may those attitudes be related to employees' critical job outcomes, such as customer orientation and extra-role customer service. Both of these outcomes are perceived as "critical" due to their importance in "highly people-centred business" (Brownell, 2004, p. 2), where delivery of exceptional service quality is crucial for survival and success (Karatepe \& Uludag, 2008).

The research value of this study may result from the fact that still "there is much to be done to investigate the work-life needs of this industry" (Mulvaney et al., 2007, p. 82). Moreover, there are a number of gaps given conflicts in the work-family interface and their effects on employees' outcomes (Karatepe \& Baddar, 2006), and previous studies have been conducted in different countries and socio-cultural backgrounds, including China (Pan, 2018); Taiwan (Dai et al., 2016), Ghana (Gamor et al., 2014); Nigeria (Karatepe, 2011), Australia (McNamara et al., 2011), and Northern Cyprus (Karatepe \& Kilic, 2007). Thus, this study may extend the research findings into a new social and cultural context, namely the hospitality industry in East-Central Europe. Moreover, this study is also among the first that examine the proposed relationships in one conceptual model, taking contact hotel employees in Poland as its setting.

\section{LITERATURE REVIEW}

Work and family are two important domains of in the lives of adults (Karatepe, 2011), who share their time and energy between those two spheres (Tomaszewska-Lipiec, 2014) that may compete with each other for these "scarce and finite" resources, depleted each day during various activities (Byrne \& Canato, 2017, p. 105). 
However, both social and workplace changes that have taken place over the last decades have influenced the way people spend their time in and out of the work (Byrne \& Canato, 2017). For example, due to radical technological and communications changes, the availability of employees and a round-the-clock access to them has significantly increased, making work more demanding without clear boundary lines (Bohdziewicz, 2014). Additionally, in today's highly competitive business with fast-paced changes, hotel organizations face increasing pressure "to do more with fewer resources" (Lee \& Ok, 2015, p. 84) putting more demands on their employees to be more effective. This may lead to a number of difficulties in successfully balancing work and home life requirements, having a detrimental effect on individuals' attitudes and behaviours at work, including absenteeism, decrease in productivity or unhappy customers (Byrne \& Canato, 2017).

Work-family conflict is defined as "a form of interrole conflict in which the role pressures from the work and family domains are mutually incompatible in some respect" (Greenhaus \& Beutell, 1985, p. 77). Thus, participation in one role (work or family) makes it more difficult to participate in the other role (family or work) (Greenhaus \& Beutell, 1985; Mulvaney et al., 2007). Work-family conflict can be conceptualised on the basis of the role theory (Tomaszewska-Lipiec, 2014; Mansour \& Tremblay, 2016; Baka, 2012; Gamor et al., 2014), according to which this inter-role conflict increases job stress because of conflicting demands which deplete resources (such as time or energy) necessary to fulfil both family and work duties (Mansour \& Tremblay, 2016). Negative relationships between various life domains are specifically postulated in the resource drain model, which takes into account a person's limited store of resources (Mulvaney et al., 2007; Amstad $\&$ Semmer, 2009). If some resources are accumulated too much in one domain, then they are missing in another one (Amstad \& Semmer, 2009). Thus, both work and family roles may compete for individuals' resources; however, the strain generated by this competition may lead to many negative consequences in both of these domains (Mulvaney et al., 2007).

Following the literature, two directions in the work-family conflict can be distinguished: family to work conflict (FWC), when family interferes with work, and work to family conflict (WFC), when demands and strain created by the job and time devoted to it interfere with performing employees' family responsibilities (Netemeyer et al., 1996; Bellavia \& 
Frone, 2005; Casper et al., 2011). Although both work-family conflict and family-work conflict are key stressors experienced by employees in the hospitality industry (Dai et al., 2016), of particular interest in this study is WFC, as researchers find that people generally report greater work-family conflict than family-work conflict (Casper et al., 2002). Moreover, it is argued that WFC is stronger, more widespread and harmful to employees and their mental health (Baka, 2012).

\section{CONCEPTUAL MODEL AND HYPOTHESES DEVELOPMENT}

Based on relevant literature review and previous empirical findings, this study develops and tests a conceptual model where a relationship between work-family conflict (WFC) and employees' depersonalisation (DEP) (as a dimension of job burnout) with their critical outcomes, such as a decrease in both customer orientation (C_O) and extra-role customer service (EX_R SERVICE), is examined (Figure 1).



Figure 1. Conceptual model

Note: WFC (work-family conflict); DEP (depersonalization); C_O (customer orientation); EX_R SERVICE (extra-role customer service).

Source: own elaboration.

From a theoretical perspective, the Conservation of Resources (COR) Theory (Hobfoll, 1989) provides useful guidelines for the conceptual model developed in this study. It posits that people strive to obtain, maintain and preserve resources (Hobfoll, 2002), which are defined as "objects, personal characteristics, conditions, or energies that are valued in their own right, or that are valued because they act as conduits to the achievement or protection of valued resources" (Hobfoll, 2001, p. 339). 
Stress occurs in a workplace in which individuals face a threat of losing certain valued resources, actually lose them or do not obtain them after substantially investing in them (Hobfoll, 2002). In view of the COR theory assumptions and in the light of previous studies, employees may lose certain resources (e.g. time and energy) in the process of juggling their work and family responsibilities (Ahmad, 2010; Yavas et al., 2008; Karatepe \& Uludag, 2007; Karatepe \& Kilic, 2007; Mansour \& Tremblay, 2016), which may result in employees' burnout and its detrimental effects on certain behavioural and attitudinal outcomes, including turnover intentions, a decrease in organisational commitment and lower job satisfaction (Lee \& Ashforth, 1996).

Specifically, previous studies (e.g. Ahmad, 2010; Mete et al., 2014; Rubab, 2017), including those from the hospitality industry, provide support that work-family conflict may lead to employees' burnout when individuals are facing difficulties stemming from problems in combining their work and family roles. For example, in a study among hotel employees in Northern Cyprus, Karatepe and Uludag (2007) demonstrated that work-family conflict is positively related to employees' emotional exhaustion. Similar results were achieved in a study by Yavas et al. (2008) focusing on frontline hotel employees in Turkey and Karatepe's study (2010) among hotel employees in Albania. Another study by Karatepe et al. (2010) conducted among hotel employees in Ankara also indicated that employees facing work-family conflict become more emotionally exhausted and disengaged.

Burnout encompasses three components (Maslach \& Jackson, 1981). Beside emotional exhaustion, the notion of burnout also includes depersonalization and diminished personal accomplishment (Cordes \& Dougherty, 1993). However, of particular interest in this study is depersonalisation that is a stress response unique to burnout (Cordes \& Dougherty, 1993). It represents the interpersonal context dimension of burnout, and refers to "negative, callous, or excessively detached response to various aspects of the job" (Maslach et al., 2001, p. 399). In other words, it is an attempt to put distance between oneself and others (Maslach et al., 2001). Thus, depersonalization (or dehumanization) is reflected in treating individuals as objects rather than people (Cordes \& Dougherty, 1993). Development of such negative and cynical attitudes and feelings towards others can be linked to the experience of emotional exhaustion (Maslach \& Jackson, 1981). It is underlined that when employees reach the point of extreme exhaustion due to 
depletion of their psychological resources, they may reduce their job involvement by withdrawing themselves from their work (Lee \& Ok, 2013). Thus, while chronic and excessive job demands drain employees' resources making them emotionally exhausted, depersonalisation may occur as a defensive coping strategy, providing a certain "emotional buffer" between a person and the job demands (Cordes \& Dougherty, 1993, p. 624) making employees less responsive to and less involved in their customers' needs (Lee \& Ok, 2013).

Due to specific work characteristics, hospitality employees are among those particularly prone to become emotionally exhausted and suffer depersonalisation (Lee \& Ok, 2013), which may have serious consequences for their well-being (Lin et al., 2014). As underlined before, hotel employees may lose their resources while managing their work and family roles. Posing a threat to use up employees' resources, the work-family conflict may lead to burnout (including depersonalization) (Lin et al., 2014; Mansour \& Tremblay, 2016) thus increasing employees' detachment from work and their emotional callousness. For example, in Lin et al.'s (2014) study among employees of various sectors of tourism and hospitality in Taiwan, it was proved that work and leisure conflicts (WLC), perceived as extension of work-family conflict, was significantly and positively related to burnout (emotional exhaustion and depersonalisation). Similarly, in one of the latest studies by Mansour and Tremblay (2016) on the hotel industry in Quebec, a positive effect of work and leisure conflict on hotel employees' depersonalization was reported.

Therefore, in line with the above theoretical consideration and in consistence with the previous empirical findings, the following hypothesis is proposed:

H1: There is a positive relationship between work-family conflict and hotel employees' depersonalisation.

One of the challenge for a hospitality organisation is the fact that both service quality and service value are defined not by managers, auditors or rating organisations; they are totally defined in the minds of guests (Ford et al., 2012) who are the final arbiter of the quality of service interaction (Ford \& Heaton, 2001). Thus, unsurprisingly, the hospitality industry heavily relies on their employees who play a critical role in accommodating customers' various needs and often 
go beyond what is expected to provide exceptional hospitality service experience. Therefore, both hotel employees' customer orientation and their extra-role customer service are perceived as critical in the hospitality industry

It is well known that service quality strongly depends on customer-oriented behaviours of employees in frontline positions (Bettencourt $\&$ Brown, 2003). Customer-oriented employees are likely to perceive people and the work environment "through the lens of "commitment to service quality' approach” (Karatepe \& Douri, 2012, p. 140). They are attentive and genuinely caring about customers (Wang et al., 2017).

Extra-role behaviour is one of the types of prosocial service behaviours frequently discussed in previous studies (Tsaur et al., 2014). It refers to "discretionary behaviours of contact employees in serving customers that extend beyond formal role requirements" (Bettencourt \& Brown, 2003, p. 41). It is underlined that employees who can delight the customers through providing them with "little extras," "extra attention" or exceptional service are perceived today greatly importance (Bettencourt \& Brown, 2003, p. 41; Tsaur \& Lin, 2004, p. 472), particularly in hospitality where guests are no longer looking for only typical accommodation services; they are looking for unique and unforgettable experiences which could be provided by a service of an exceptional level, far beyond their expectations (Wang et al., 2017). Therefore, as underlined in Karatepe's (2013) study, hospitality strongly needs frontline employees who will be likely to help customers through going out of their way. However, in such stressful work environment as hospitality (e.g. Hwang et al., 2014) that is particularly susceptible to antecedents of job burnout (O'Neill \& Xiao, 2010), managers may face real difficulties with high-performing, customer-oriented staff. Experiencing burnout may lead to many negative consequences for the quality of provided services, as exhausted employees may feel limited patience in direct interactions with customers, and their customer-oriented attitudes and behaviours may decrease, as in Lee et al.'s (2012) study among frontline employees in Korean luxury hotels which proved a negative impact of burnout (emotional exhaustion) on employees' customer orientation. Similar findings were achieved in a more recent study by Choi et al. (2014) demonstrating a negative relationship between emotional exhaustion and customer orientation among frontline tourist service providers. 
Based on the above, it can also be assumed that in the case of this study hotel employees' customer orientation and extra-role customer service can be diminished by burnout, particularly depersonalisation, as one of its dimensions. It is difficult to gain a high quality of service or a sense of accomplishment when employees are helping customers toward whom they are indifferent (Maslach et al., 2001). Because of highly intense interactions with guests which, as literature underlines, are often "inherently difficult, upsetting, and emotionally charged," frontline hotel employees are likely to have higher levels of stress, consequently, leading to their detachment from customers (Lee \& Ok, 2013, p. 21). As reported in a study of Lee and Ok (2013), among hotel employees in the United States, the higher hotel employees' depersonalisation is the lower their attitudinal service orientation, perceived as willingness to devote their time and effort to satisfy guests and meet their needs. Therefore, it can be suggested that when hotel employees experience depersonalisation, their interests in customers' needs and their exceptional attentiveness towards hotel guests may decrease. Such employees also may not be likely to go the "extra mile" to provide an excellent level of service beyond what is expected of them.

Thus, based on the above, the following hypothesis is proposed:

H2: There is a negative relationship between depersonalisation and both hotel employees' customer orientation (a) and their extra-role customer service (b).

\section{METHODS}

\section{Data collection procedure}

The research was conducted among employees working in hotels of the Pomerania Province, a popular tourist destination in Northern Poland, with extensive accommodation facilities (Strategia Rozwoju..., 2012). The above-average attractiveness and well-developed tourist infrastructure contribute to increasing tourist arrivals in the region. In 2016, Pomerania was visited by nearly 9 million tourists (Szumny, 2017). Understandably, the economic potential of the region is also based on tourism development (Strategia Rozwoju..., 2012). The research was conducted in January and February 2018. In this study, in line with 
previous works (e.g. Lee-Ross, 2005), a convenience sample of hotels was applied. They were chosen due to mutual cooperation and/or familiarity between the researcher and these hotels' managers (Kim, 2008; Lam \& Chen, 2012), who agreed to participate in this study after meeting and explaining its purpose in detail. The studied hotels represent full-service establishments of medium standard with offer for both business and leisure. They have various functional departments, which increases access to a wide range of contact staff (O'Neill \& Davis, 2011). Moreover, it is worth mentioning that data collected from different departments may reduce a single-department bias and therefore support external validity of the study (Chang \& Teng, 2017).

Employees working in contact positions were chosen as study participants due to the nature of their boundary-spanning positions and spending most of their working time on dealing directly with customers (Karatepe et al., 2006). It is underlined that they can influence guests' positive emotions and experiences, based on which customers build their loyalty to the organization (Lashley, 2008).

A survey instrument was used to collect the data. All questionnaires were anonymous and included assurance of confidentiality. They were distributed in packs including a cover letter and a return envelope. Employees were informed that their participation was voluntary and filled in the questionnaires in a self-administrated manner during their working time.

\section{Measurement}

To operationalise the study constructs, the existing and well-established multiple-item scales were obtained from the relevant literature and previous studies, including those from hospitality, where they have received considerable empirical attention.

Work-family conflict (WFC) was measured via five items in line with Karatepe and Kilic (2007) and Karatepe and Sokmen (2006), who based on Netemeyer et al. (1996) and Boles et al. (2001), and measured work-family conflict among frontline hotel employees in Northern Cyprus and Turkey, respectively. These scale items were also successfully used in other, prior studies from hospitality (e.g. Karatepe et al., 2010; Karatepe \& Uludag, 2007; Yavas et al., 2008).

To measure customer orientation (C_O), three items were taken from Lee (2014), who successfully used them in his study among frontline 
employees at hotels in Seoul (Korea). Extra-role customer service (EX_R SERVICE) was assessed using five items from Bettencourt and Brown (1997). Use of this scale for operationalising extra-role customer service is prevalent in the relevant hospitality literature (e.g. Karatepe, 2013; 2015).

The five depersonalisation (DEP) items came from Mansour and Tremblay (2016), who based on the Maslach Burnout Inventory (MBI) scale and conducted their study in the hotel industry in Quebec. Each item was rated on a five-point scale ranging from $1=$ strongly disagree to $5=$ strongly agree. The survey instrument was originally prepared in English and then translated into Polish via the back-translation method. Feedback from a pilot group confirmed that employees had no difficulties in understanding the scale items.

The scale's reliability was assessed by Cronbach's alpha (Table 1). All values were above the commonly accepted cut-off point of 0.70 (Nunnally, 1978), demonstrating good internal consistency, with an exception of C_O that was at a slightly below yet still regarded as adequate level (Kwok et al., 2012).

In this study descriptive statistics have been provided, including measures of central tendency and variability. Pearson's correlation analysis was also performed to test the proposed relationship between study variables. The collected data were analysed using Statistical Package for Social Sciences (SPSS), version 25.

\section{RESULTS}

The majority of the respondents were women (83.1\%). Over half of the study participants (60\%) were aged between 21 and 30 years, a quarter (25.4\%) were in the age bracket of 31-40 years old, the remaining ones were either older (10.8\%) or below 20 years old (3.8\%). Regarding education, $46.9 \%$ of the respondents declared a university degree, and $40.8 \%$ had secondary school education. The remaining subjects had vocational education (12.3\%). Of particular interest in this study was also employees' work experience. For $47.7 \%$ of the subjects, the total work experience in the hospitality industry had been between 1 and 5 years; $20 \%$ of the study participants declared the length of working experience from 6 to 15 years; $18.6 \%$ had been working in the industry for longer than 15 years, and the smallest group of the 
surveyed (13.7\%) had been working in the hospitality industry below 1 year. The above data show that the studied group seems to have quite rich working experience in the hospitality industry, thus they may provide adequate feedback on the relationships analysed in this study.

The results showed that hotel employees in this study perceived themselves as relatively high in customer orientation and extra-role customer service (Table 1). Specifically, they agreed that they always had the customers' best interests in mind and voluntarily assisted their guests even if it meant going beyond their job requirements. They also reported a higher level of experiencing work-family conflict than depersonalisation scoring relatively high on the fact that due to their job they were missing important family and social activities and could not get involved as much as they would like to in keeping close relationships with their family, spouse and friends. In the context of depersonalisation, among other aspects, the study participants referred to their feelings of treating some hotel guests as impersonal objects and pointing to the fact that customers blamed them for some of their problems.

Table 1. Means, standard deviations, and reliabilities

\begin{tabular}{|l|c|c|c|}
\hline \multicolumn{1}{|c|}{ Scale items } & Mean & SD & Alpha \\
\hline Work-Family Conflict (WFC) & 2.58 & 1.04 & .92 \\
\hline $\begin{array}{l}\text { The demands of my work interfere with home, family, and social } \\
\text { life. }\end{array}$ & 2.70 & 1.24 & \\
\hline $\begin{array}{l}\text { Because of my job, I cannot involve myself as much as I would } \\
\text { like in maintaining close relations with my family, spouse, or } \\
\text { friends. }\end{array}$ & 2.70 & 1.25 & \\
\hline $\begin{array}{l}\text { Things I want to do at home do not get done because of the de- } \\
\text { mands my job puts on me. }\end{array}$ & 2.38 & 1.07 & \\
\hline $\begin{array}{l}\text { I often have to miss important family and social activities because } \\
\text { of my job. }\end{array}$ & 2.78 & 1.31 & \\
\hline $\begin{array}{l}\text { There is a conflict between my job and the commitments and } \\
\text { responsibilities I have to my family, spouse, or friends. }\end{array}$ & 2.35 & 1.07 & \\
\hline Depersonalisation (DEP) & 2.02 & .70 & .78 \\
\hline I feel I treat some customers as if they were impersonal objects. & 2.16 & .94 & \\
\hline I've become more callous toward people since I took this job. & 1.89 & .97 & \\
\hline I worry that this job is hardening me emotionally. & 1.91 & .96 & 1.87 \\
\hline I don't really care what happens to some customers. & 2.27 & 1.02 & \\
\hline I feel customers blame me for some of their problems. & .95 & \\
\hline
\end{tabular}


Table 1. cd.

\begin{tabular}{|c|c|c|c|}
\hline Scale items & Mean & SD & Alpha \\
\hline Customer orientation $\left(C_{-} O\right)$ & 4.09 & .56 & .68 \\
\hline I enjoy interacting with customers. & 4.25 & .67 & \\
\hline I always have the customers' best interests in mind. & 4.36 & .67 & \\
\hline $\begin{array}{l}\text { I am willing to spend more time to properly meet a customer's } \\
\text { needs. }\end{array}$ & 3.66 & .81 & \\
\hline Extra-Role Customer Service (EX_R SERVICE) & 4.07 & .68 & .92 \\
\hline $\begin{array}{l}\text { I voluntarily assist customers even if it means going beyond job } \\
\text { requirements. }\end{array}$ & 4.22 & .73 & \\
\hline $\begin{array}{l}\text { I help customers with problems beyond what is expected or re- } \\
\text { quired. }\end{array}$ & 4.12 & .77 & \\
\hline $\begin{array}{l}\text { I often go above and beyond the call of duty when serving custom- } \\
\text { ers. }\end{array}$ & 3.85 & .88 & \\
\hline I willingly go out of his/her way to make a customer satisfied. & 4.14 & .72 & \\
\hline I frequently go out the way to help a customer. & 4.03 & .81 & \\
\hline
\end{tabular}

$\mathrm{N}=130$

Note: WFC (work-family conflict); DEP (depersonalization); C_O (customer orientation); EX_R SERVICE (extra-role customer service).

Source: based on own study results.

To verify the study hypotheses, Person's correlation was applied. As depicted in Figure 2, all correlations among the study constructs were significant and in the predicted directions.

The study findings revealed that there is a positive and significant correlation between work-family conflict and depersonalisation. It may suggest that in this study an increase in experiencing work-family conflict may play an important role in elevating contact employees' feelings of depersonalisation making them more callous, uninterested and uncaring about guests and their problems.

This study results also reported negative and significant correlations between DEP and both customer orientation and extra-role customer service. This may indicate that a higher level of employees' depersonalisation decreases their enjoyment of serving customers and fulfilling their needs. Moreover, through feelings of detachment and cynical attitudes towards others such employees are not likely to make extra effort to provide excellent service. In other words, feelings 


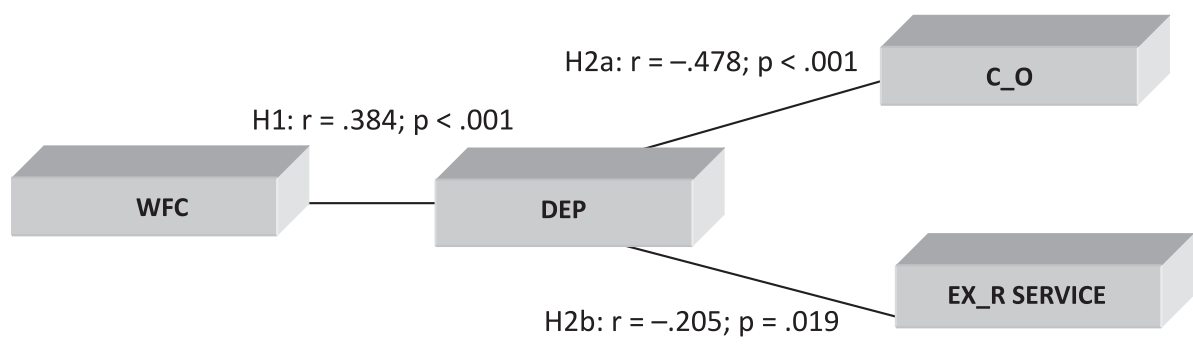

Figure 2. Verified model

$\mathrm{N}=130$

Note: WFC (work-family conflict); DEP (depersonalization); C_O (customer orientation); EX_R SERVICE (extra-role customer service)

Source: based on own study results

of depersonalisation may limit employees' predisposition towards serving customers in an empathetic and caring manner.

\section{DISCUSSION AND IMPLICATIONS}

This study developed and tested a research model that investigated the relationships between work-family conflict and depersonalisation, as one of the dimensions of burnout, and its critical outcomes for the quality of service. All hypothesised relationships received support from the empirical data.

More specifically, the study findings showed that the higher the level of work-family conflict that exhausts employees' valuable and limited resources, the higher the risk of job burnout (depersonalisation) that may be negatively related to hotel employees' customer orientation and their extra-role customer service. It may seriously threaten organisation's effectiveness, as, undoubtedly, hospitality organisations more than ever constantly have to improve the quality of hotel services in order to be competitive (Mansour \& Tremblay, 2016). However, ironically, through increasing pressure on employees to be more effective, hotel organisations may actually gain quite the opposite results, since due to excessive job demands, employees lose their limited resources of time, talent, and energy, thus having difficulties in fulfilling successfully their family responsibilities. As a result, they may experience stress and distance from their work through putting less interest in guests' 
needs and less effort in providing them with excellent service. Thus, answering the question: "What is wrong with quality of hotel service?" one of the answers may lay in the work-family conflict experienced by hotel employees.

This study contributes to the extant body of knowledge over workfamily conflict in general and specifically in hospitality management literature by broadening research on the behavioural and attitudinal consequences of WFC in the hospitality industry. Findings of this study are consistent with the notion of the COR theory (Hobfoll, 1989; 2002; Lee \& Ashforth, 1996) and relate to the prior work from hospitality that examined the relationship between WFC and burnout (or its dimensions) (e.g. Karatepe \& Uludag, 2007; Yavas et al., 2008; Karatepe et al., 2010; Karatepe, 2010) and the consequences of burnout (or its dimensions) for employees and their critical job outcomes (e.g. Chen \& Kao, 2012; Choi et al., 2014; Lee et al., 2012; Lee \& Ok, 2013).

Although the hospitality industry has its specific characteristics that contribute to conflict, hotel managers may support their employees to deal effectively with "the unique demands of a $24 / 7$ service industry" (Mulvaney et al., 2007, p. 81) making employees feel that they work and family roles can be successfully managed. However, firstly, friendly organisational culture that is oriented on personal lives of hotel employees should be developed as an integrated and transparent approach addressing the issue of work-life balance and serves as a basis for a variety of innovative management practices. If successfully implemented in an organization, they would provide employees with real resources to alleviate stress and effectively cope with WFC.

Secondly, keeping in mind that frontline service jobs require particularly long working hours and excessive workloads (Karatepe et al., 2013) hotel employees should have more autonomy in organising their working hours (Mansour \& Tremblay, 2016) and be empowered to manage customer interactions successfully (Enz \& Siguaw, 2000). Moreover, employees should be offered a variety of family support benefits (e.g. employee assistance programs, childcare, family and sabbatical leaves, etc.) (Zhao \& Mattila, 2013; Enz \& Siguaw, 2000; Karatepe, 2011) and given a possibility to choose benefit options that best fit their needs (Zhao \& Mattila, 2013). Furthermore, hotel organisations should measure the extent to which their work-life balance 
programs or benefits work effectively through collecting feedback from employees. Through creating such family-friendly work environment hotel companies may also increase their positive image as employers could attract a pool of qualified and talented candidates for hotel jobs (Karatepe, 2009; Zhao et al., 2011).

Thirdly, it is proved that supervisor support alleviates hotel employees' work-family conflict (Karatepe \& Kilic, 2007). Therefore, social support, particularly from supervisors, who are perceived as organization's representatives, may play an important role in determining the effectiveness of family-friendly polices (Mulvaney et al., 2007). However, because people "do not experience the world in the same way" (Mulvaney et al., 2007, p. 76), it is pivotal to appreciate differences between them (Wong \& Ko, 2009). Therefore, supervisors/managers should listen to their employees whose individual needs cannot be unnoticed. They should show concern, understanding and empathy for subordinates' work and family-related problems and support them in dealing with these difficulties (Dai et al., 2016; Pan, 2018).

Fourthly, calling meetings with employees and their families is also recommended, as managers might have a great possibility to explain any difficulties that are associated with specific frontline service jobs and through that gain the families' understanding and support while employees are facing work-related problems (Karatepe, 2009). Moreover, organizing informal meetings and individual sessions may also help managers to assess whether their subordinates are experiencing high levels of job stress and work pressure (Kim \& Jogaratnam, 2010).

Finally, hotel employees also need recovery opportunities from their daily work stress, especially that effort expenditure at work may exploit their resources and cause mood- and performance-related strain reactions (Sonnentag, 2003). Therefore, any recovery possibilities, both internal (during the workday) and external (outside working hours) (Tromp \& Blomme, 2012), are critical to prevent hotel employees from the harmful impact of their excessive work demands. In this light, particularly leisure-related activities may help employees restore their depleted resources. That is why, managers should encourage employees to practice various activities, inform them about their benefits, and organize regular tourism-related programs and incentive tours as job-related motivators (Suhartanto et al., 2018) that would involve employees and their families. 


\section{Limitations and directions for future research}

As with all empirical research, this study also has a few limitations which may provide implications for future research. Firstly, this study included only selected hotels from Northern Poland; therefore, the study results cannot be generalised. Additionally, fairly low values of the correlation coefficients (e.g. $\mathrm{r}=-.205$ ) requires interpreting the study results with some caution. Thus, future research with both larger samples and different hospitality settings are recommended to overcome these limitations and validate the results achieved in this study. Secondly, because all variables were measured through self-reporting questionnaires, the results might have been influenced by a common method bias (Jung \& Yoon, 2014). Therefore, although some procedures were taken to minimise this threat, including ensuring anonymity and confidentiality of individual responses, future studies should apply other sources of data collection (e.g. managers' or customers' evaluations) to avoid concerns of such bias (Lee, 2014; Karatepe, 2011).

This study also opens several avenues for future research. It could be interesting to investigate a research model based on the employees' socio-demographic characteristics, as they may play a useful role in the relationships examined in this study and it could provide a broader picture for study results. It is also recommended to focus on the positive side of the relationship between work and family domains, as participation in multiple roles may also produce a number of benefits (Karatepe, 2008). This is especially important, as so far these issues have received rather scanty empirical attention (Mulvaney et al., 2007). Thus, it could be particularly interesting to examine the relationships between work-family facilitation and the job outcomes analysed in this study. Finally, since most findings are based on quantitative studies, qualitative studies are also strongly recommended for future research (Karatepe, 2008).

\section{CONCLUSIONS}

Given the critical role of frontline employees in the service delivery process, many service companies seek a competitive advantage by relying on their employees to satisfy and delight customers (Lee-Ross, 
2003). This is particularly observed in the hospitality industry that is experiencing more than ever the increased focus on the delivery of excellent products and services to customers (Lee et al., 2016). However, due to the demanding nature of hospitality jobs, many employees lose their limited resources of time and energy through focusing on their work-related activities and thus experience difficulties in successfully balancing their work and non-work areas of life.

Findings of this study suggest that WFC may negatively relate to hotel employees' caring and empathetic attitudes towards guests and their service behaviours, which finally may have harmful consequences for the perceived service quality and guests' satisfaction. Therefore, being aware of such threats, hotel managers should do their best to provide appropriate practices addressing the issue of work-life balance in the hospitality workplace where "service with a smile" (Medler-Liraz, 2014, p. 63) is one of the primary objectives in highly customer-oriented hospitality business.

\section{REFERENCES}

Ahmad, A. (2010). Work-family conflict among junior physicians: Its mediating role in the relationship between role overload and emotional exhaustion. Journal of Social Sciences, 6(2), 265-271.

Alhelalat, J.A., Habiballah, M.A. \& Twaissi, N.M. (2017). The impact of personal and functional aspects of restaurant employee service behaviour on customer satisfaction. International Journal of Hospitality Management, 66, 46-53.

Amstad, F.T. \& Semmer, N.K. (2009). Recovery and the work-family interface. In: S. Sonnentag, P.L. Perrewé, D.C. Ganster (eds.). Current Perspectives on Job-Stress Recovery Research in Occupational Stress and Well-being, Vol. 7 (pp. 125-166). Bingley: Emerald Group Publishing Limited.

Baka, Ł. (2012). Wymagania w pracy i w rodzinie a satysfakcja z pracy i satysfakcja z małżeństwa: mediująca rola konfliktów między praca a rodzina. Polskie Forum Psychologiczne, 17(1), 171-186.

Bellavia, G.M. \& Frone, M.R. (2005). Work-family conflict. In: J. Barling, E.K. Kelloway \& M.R. Frone (eds.). Handbook of Work Stress (pp. 113-148). Thousand Oaks: Sage Publications, Inc.

Bettencourt, L.A. \& Brown, S.W. (1997). Contact employees: relationships among workplace fairness, job satisfaction and prosocial service behaviors. Journal of Retailing, 73(1), 39-61. 
Bohdziewicz, P. (2014). Problemy równowagi praca-życie jako trudne doświadczenie realizatorów nowych wzorców kariery zawodowej. In: R. Tomaszewska-Lipiec (ed.). Relacje praca-życie pozazawodowe droga do zrównoważonego rozwoju jednostki (pp. 194-210). Bydgoszcz: Wydawnictwo Uniwersytetu Kazimierza Wielkiego.

Boles, J.S., Howard, W.G. \& Donofrio, H.H. (2001). An investigation into the inter-relationships of work-family conflict, family-work conflict and work satisfaction. Journal of Managerial Issues, 13(3), 376-390.

Brownell, J. (2004). Ingredients for success in career development. Hospitality Review, 22(2), 1-17. http://digitalcommons.fiu.edu/hospitalityreview/vol22/ iss2/1 (accessed: 20 $0^{\text {th }}$ March 2018).

Byrne, J.M. \& Canato, A. (2017). It's been a hard day's night: Work family interface and employee engagement. Organizational Dynamics, 46, 104-112.

Casper, W.J., Martin, J.A., Buffardi, L.C. \& Erdwins, C.J. (2002). Work-family conflict, perceived organizational support, and organizational commitment among employed mothers. Journal of Occupational Health Psychology, 7(2), 99-108.

Casper, W.J., Harris, Ch., Taylor-Bianco, A. \& Wayne, J.H. (2011). Work-family conflict, perceived supervisor support and organizational commitment among Brazilian professionals. Journal of Vocational Behavior, 79, 640-652.

Chang, J.-H. \& Teng, Ch.-Ch. (2017). Intrinsic or extrinsic motivations for hospitality employees' creativity: The moderating role of organization-level regulatory focus. International Journal of Hospitality Management, 60, 133-141.

Chen, Ch.-F. \& Kao, Y.-L. (2012). Investigating the antecedents and consequences of burnout and isolation among flight attendants. Tourism Management, 33(4), 868-874.

Cheng, Ch.-H. (2011). A study of critical factors of the job involvement for hotel employees: Taking hotels in Taiwan as an example. International Journal of Hospitality Management, 30, 990-996.

Choi, C.H., Kim, T. (T)., Lee, G. \& Lee, S.K. (2014). Testing the stressor-strain-outcome model of customer-related social stressors in predicting emotional exhaustion, customer orientation and service recovery performance. International Journal of Hospitality Management, 36, 272-285.

Chu, K.H., Baker, M.A. \& Murrmann, S.K. (2012). When we are onstage, we smile: The effects of emotional labor on employee work outcomes. International Journal of Hospitality Management, 31(3), 906-915.

Cordes, C.L. \& Dougherty, T.W. (1993). Review and an integration of research on job burnout. Academy of Management Review, 18(4), 621-656. 
Dai, Y.-D., Chen, K.-Y. \& Zhuang, W.-L. (2016). Moderating effect of work-family conflict on the relationship between leader-member exchange and relative deprivation: Links to behavioral outcomes. Tourism Management, 54, 369-382.

Enz, C.A. \& Siguaw, J.A. (2000). Best practices in human resources. Cornell Hotel and Restaurant Administration Quarterly, 41(1), 48-61.

Faulkner, B. \& Patiar, A. (1997). Workplace induced stress among operational staff in the hotel industry. International Journal of Hospitality Management, 16(1), 99-117.

Ford, R.C. \& Heaton, Ch.P. (2001). Managing your guest as a quasi-employee. Cornell Hotel and Restaurant Administration Quarterly, 42(2), 46-55.

Ford, R.C., Sturman, M.C. \& Heaton, Ch.P. (2012). Managing Quality Service in Hospitality: How Organizations Achieve Excellence in the Guest Experience. Clifton Park: Delmar, Cengage Learning.

Gamor, E., Amissah, E.F. \& Boakye, K.A.A. (2014). Work-family conflict among hotel employees in Sekondi-Takoradi Metropolis, Ghana. Tourism Management Perspectives, 12, 1-8.

Greenhaus, J.H. \& Beutell, N.J. (1985). Sources of conflict between work and family roles. Academy of Management Review, 10(1), 76-88.

Grobelna, A., Sidorkiewicz, M. \& Tokarz-Kocik, A. (2016). Job satisfaction among hotel employees: Analyzing selected antecedents and job outcomes. Case study from Poland. Argumenta Oeconomica, 2(37), 281-310.

Hobfoll, S.E. (1989). Conservation of resources: A new attempt a conceptualizing stress. American Psychologist, 44(3), 513-524.

Hobfoll, S.E. (2001). The influence of culture, community, and the nested-self in the stress process: Advancing conservation of resources theory. Applied Psychology: An International Review, 50(3), 337-421.

Hobfoll, S.E. (2002). Social and psychological resources and adaptation. Review of General Psychology, 6(4), 307-324.

Hwang, J., Lee, J. (J.), Park, S., Chang, H. \& Kim, S.S. (2014). The impact of occupational stress on employee's turnover intention in the luxury hotel segment. International Journal of Hospitality and Tourism Administration, 15(1), 60-77.

Jung, H.S. \& Yoon, H.H. (2014). Antecedents and consequences of employees' job stress in a foodservice industry: Focused on emotional labor and turnover intent. International Journal of Hospitality Management, 38, 84-88.

Karatepe, O.M. \& Baddar, L. (2006). An empirical study of the selected consequences of frontline employees' work-family conflict and family-work conflict. Tourism Management, 27(5), 1017-1028. 
Karatepe, O.M. \& Sokmen, A. (2006). The effects of work role and family role variables on psychological and behavioral outcomes of frontline employees. Tourism Management, 27(2), 255-268.

Karatepe, O.M. (2008). Work-family conflict and facilitation: Implications for hospitality researchers. In: D.V. Teasone (ed.). Handbook of Hospitality Human Resources Management (pp. 237-264). London-New York: Taylor \& Francis Group.

Karatepe, O.M. (2009). An investigation of the joint effects of organisational tenure and supervisor support on work-family conflict and turnover intentions. Journal of Hospitality and Tourism Management, 16(1), 73-81.

Karatepe, O.M. (2011). Job resourcefulness as a moderator of the work-family conflict - job satisfaction relationship: A study of hotel employees in Nigeria. Journal of Hospitality and Tourism Management, 18(1), 10-17.

Karatepe, O.M., Uludag, O., Menevis, I., Hadzimehmedagic, L. \& Baddar, L. (2006). The effects of selected individual characteristics of frontline employee performance and job satisfaction. Tourism Management, 27(4), 547-560.

Karatepe, O.M (2013). High-performance work practices and hotel employee performance: The mediation of work engagement. International Journal of Hospitality Management, 32, 132-140.

Karatepe, O.M. \& Douri, B.G. (2012), Does customer orientation mediate the effect of job resourcefulness on hotel employee outcomes? Evidence from Iran. Journal of Hospitality and Tourism Management, 19, 133-142.

Karatepe, O.M. \& Karadas, G. (2014). The effect of psychological capital on conflicts in the work-family interface, turnover and absence intentions. International Journal of Hospitality Management, 43, 132-143.

Karatepe, O.M. \& Kilic, H. (2007). Relationships of supervisor support and conflicts in the work-family interface with the selected job outcomes of frontline employees. Tourism Management, 28(1), 238-252.

Karatepe, O.M. \& Uludag, O. (2007). Conflict, exhaustion and motivation: a study of frontline employees in Northern Cyprus hotels. International Journal of Hospitality Management, 26(3), 645-665.

Karatepe, O.M. \& Uludag, O. (2008). Role stress, burnout and their effects on frontline hotel employees' job performance: evidence from Northern Cyprus. International Journal of Tourism Research, 10, 111-126.

Karatepe, O.M. (2010). The effect of positive and negative work-family interaction on exhaustion: Does work social support make a difference? International Journal of Contemporary Hospitality Management, 22(6), 836-856.

Karatepe, O.M. (2015). The effects of family support and work engagement on organizationally valued job outcomes. Tourism, 63(4), 447-464. 
Karatepe, O.M., Karadas, G., Azar, A.K. \& Naderiadib, N. (2013). Does work engagement mediate the effect of polychronicity on performance outcomes? A study in the hospitality industry in Northern Cyprus. Journal of Human Resources in Hospitality \& Tourism, 12, 52-70.

Karatepe, O.M., Sokmen, A., Yavas, U. \& Babakus, E. (2010). Work-family conflict and burnout in frontline service jobs: Direct, mediating and moderating effects. E+M Ekonomie a Management, 4, 61-73.

Kim, H.J. (2008). Hotel service providers' emotional labor: The antecedents and effects on burnout. International Journal of Hospitality Management, 27(2), 151-161.

Kim, H.J., Shin, K.H. \& Umbreit, W.T. (2007). Hotel job burnout: The role of personality characteristics. International Journal of Hospitality Management, 26(2), 421-434.

Kim, K. \& Jogaratnam, G. (2010). Effects of individual and organizational factors on job satisfaction and intent to stay in the hotel and restaurant industry. Journal of Human Resources in Hospitality \& Tourism, 9(3), 318-339.

Kwok, L., Adams, Ch.R. \& Feng, D. (2012). A comparison of graduating seniors who receive job offers and those who do not according to hospitality recruiters' selection criteria. International Journal of Hospitality Management, 31(2), 500-510.

Lam, W. \& Chen, Z. (2012). When I put on my service mask: Determinants and outcomes of emotional labor among hotel service providers according to affective event theory. International Journal of Hospitality Management, 31(1), 3-11.

Lashley, C. (2008). Studying hospitality: Insights from social sciences. Scandinavian Journal of Hospitality and Tourism, 8(1), 69-84.

Lee, J. \& Ok, C.M. (2013). Examination of factors affecting hotel employees' service orientation: An emotional labor perspective. Journal of Hospitality \& Tourism Research, 20(10), 1-32.

Lee, Ch. \& Way, K. (2010). Individual employment characteristics of hotel employees that play a role in employee satisfaction and work retention. International Journal of Hospitality Management, 29(3), 344-353.

Lee, G., Kim, T., Shin, S.H. \& Oh, I.K. (2012). The managed heart: The structural analysis of the stressor-strain relationship and customer orientation among emotional labor workers in Korean hotels. International Journal of Hospitality Management, 31, 1067-1082.

Lee, J.H. \& Ok, C.M. (2015). Drivers of work engagement: An examination of core self evaluations and psychological climate among hotel employees. International Journal of Hospitality Management, 44, 84-98. 
Lee, K.-J. (2014). Attitudinal dimensions of professionalism and service quality efficacy of frontline employees in hotels. International Journal of Hospitality Management, 41, 140-148.

Lee, R.T. \& Ashforth, B.E. (1996). A meta-analytic examination of the correlates of the three dimensions of burnout. Journal of Applied Psychology, 81(2), 123-133.

Lee-Ross, D. (2003). The quintessential relationship: Service predispositions and quality assurance. In: S. Kusluvan (ed.). Managing Employee Attitudes and Behaviors in the Tourism and Hospitality Industry (pp. 263-275). New York: Nova Publishers.

Lee-Ross, D. (2005). Perceived job characteristics and internal work motivation: An exploratory cross-cultural analysis of the motivational antecedents of hotel workers in Mauritius and Australia. Journal of Management Development, 24(3), 253-266.

Lin J.-H., Wong, J.-Y. \& Ho, C.-H. (2013). Promoting frontline employees' quality of life: Leisure benefit systems and work-to-leisure conflicts. Tourism Management, 36, 178-187.

Lin, Y.-S., Huang, W.-S., Yang, C.-T. \& Chiang, M.-J. (2014). Work-leisure conflict and its associations with well-being: The roles of social support, leisure participation and job burnout. Tourism Management, 45, 244-252.

Mansour, S. \& Tremblay, D.-G. (2016). How the need for "leisure benefit systems" as a "resource passageways" moderates the effect of work-leisure conflict on job burnout and intention to leave: A study in the hotel industry in Quebec. Journal of Hospitality and Tourism Management, 27, 4-11.

Maslach, Ch. \& Jackson, S.E. (1981). The measurement of experienced burnout. Journal of Occupational Behaviour, 2(2), 99-113.

McNamara, M., Bohle, P. \& Quinlan, M. (2011). Precarious employment, working hours, work-life conflict and health in hotel work. Applied Ergonomics, 42(2), 225-232.

Medler-Liraz, H. (2014). Negative affectivity and tipping: The moderating role of emotional labor strategies and leader-member exchange. International Journal of Hospitality Management, 36, 63-72.

Mete, M., Ünal, Ö.F. \& Bilen, A. (2014). Impact of work-family conflict and burnout on performance of accounting professionals. Procedia - Social and Behavioral Sciences, 131, 264-270.

Mulvaney, R.H., O’Neill, J.W., Cleveland, J.N. \& Crouter, A.C. (2007). A model of work family dynamics of hotel managers. Annals of Tourism Research, 34(1), 66-87. 
Netemeyer, R.G., Boles, J.S. \& McMurrian, R. (1996). Development and validation of work-family conflict and family-work conflict scales. Journal of Applied Psychology, 81(4), 400-410.

Nunnally, J.C. (1978). Psychometric Theory. New York: McGraw-Hill Book Company. O’Neill, J.W. \& Davis, K. (2011). Work stress and well-being in the hotel industry. International Journal of Hospitality Management, 30(2), 385-390.

O’Neill, J.W. \& Xiao, Q. (2010). Effects of organizational/occupational characteristics and personality traits on hotel manager emotional exhaustion. International Journal of Hospitality Management, 29(4), 652-658.

Pan, S.-Y. (2018). Do workaholic hotel supervisors provide family supportive supervision? A role identity perspective. International Journal of Hospitality Management, 68, 59-67.

Poulston, J.M. (2009). Working conditions in hospitality: Employees' views of the dissatisfactory hygiene factors. Journal of Quality Assurance in Hospitality \& Tourism, 10(1), 23-43.

Qu, H. \& Zhao, X.R. (2012). Employees' work-family conflict moderating life and job satisfaction. Journal of Business Research, 65, 22-28.

Redman, T. \& Mathews, B.P. (1998). Service quality and human resource management. A review and research agenda. Personnel Review, 27(1), 57-77.

Rubab, U. (2017). Impact of work-family conflict on burnout and workplace deviant behavior: Mediating role of stress. Jinnah Business Review, 5(1), 1-10.

Sonnentag, S. (2003). Recovery, work engagement, and proactive behavior: A new look at the interface between nonwork and work. Journal of Applied Psychology, 88, 518-528.

Strategia Rozwoju Województwa Pomorskiego 2020 (2012). Załącznik nr 1 do Uchwały nr 458/XXII/12 Sejmiku Województwa Pomorskiego z dnia 24 września 2012 roku [24 ${ }^{\text {th }}$ Sept 2012] w sprawie przyjęcia Strategii Rozwoju Województwa Pomorskiego 2020. Gdańsk.

Suhartanto, D., Dean, D., Nansuri, R. \& Triyuni, N.N. (2018). The link between tourism involvement and service performance: Evidence from frontline retail employees. Journal of Business Research, 83, 130-137.

Szumny, M. (2017). Pomorska Regionalna Organizacja Turystyczna na „szóstke”. Rekordowy rok 2016. https://pomorskie.eu/-/pomorska-regionalna-organizacja-turystyczna-na-szostke-rekordowy-rok-2016 (accessed: $17^{\text {th }}$ March 2018).

Tomaszewska-Lipiec, R. (2014). Równowaga praca-życie pozazawodowe czynnikiem wspomagajacym rozwój zawodowy. Polityka społeczna, 3, 17-22.

Tromp, D.M. \& Blomme, R.J. (2012). The effect of effort expenditure, job control and work-home arrangements on negative work-home interference in the 
hospitality industry. International Journal of Hospitality Management, 31(4), 1213-1221.

Tsaur, S.H., Wang, Ch.-H., Yen, Ch.-H. \& Liu, Y.-Ch. (2014). Job standardization and service quality: The mediating role of prosocial service behaviors. International Journal of Hospitality Management, 40, 130-138.

Tsaur, S.-H. \& Lin, Y.-Ch. (2004). Promoting service quality in tourist hotels: The role of HRM practices and service behavior. Tourism Management, 25(4), $471-481$.

Walker, J.R. (2014). Introducing Hospitality. London: Pearson New International Edition.

Wang Y.-Ch., Luo, Ch.-Ch. \& Tai, Y.-F. (2017). Implementation of delightful services: From the perspective of frontline service employees. Journal of Hospitality and Tourist Management, 31, 90-104.

Wong, S. Ch.-K. \& Ko, A. (2009). Exploratory study of understanding hotel employees' perception on work-life balance issues. International Journal of Hospitality Management, 28(2), 195-203.

Xiao, Q. \& O’Neill, J.W. (2010). Work-family balance as a potential strategic advantage: A hotel general manager perspective. Journal of Hospitality \& Tourism Research, 34(4), 415-439.

Yavas, U., Babakus, E. \& Karatepe, O.M. (2008). Attitudinal and behavioral consequences of work-family conflict and family-work conflict. Does gender matter? International Journal of Service Industry Management, 19(1), 7-31.

Zhao X. (R.), Qu, H. \& Ghiselli, R. (2011). Examining the relationship of work-family conflict to job and life satisfaction: A case of hotel sales managers. International Journal of Hospitality Management, 30, 46-54.

Zhao, X. (R.) \& Mattila, A.S. (2013). Examining the spillover effect of frontline employees' work-family conflict on their affective work attitudes and customer satisfaction. International Journal of Hospitality Management, 33, 310-315. 


\section{CO JEST NIE TAK Z JAKOŚCIA OBSKUGI W HOTELU? KRYTYCZNA ROLA KONFLIKTU PRACA-RODZINA I JEGO NEGATYWNYCH SKUTKÓW}

\section{Abstrakt}

Tło badań. Na współczesnym, wysoce konkurencyjnym rynku hotelarze stają dziś w obliczu rosnącej presji, by osiagać wciąż wyższe rezultaty przy mniejszej ilości zaangażowanych zasobów, stawiając przy tym coraz większe wymagania swoim pracownikom. Prawda jest jednak, że pracownicy branży hotelarskiej funkcjonuja w szczególnie stresujacym środowisku pracy. Doświadczają oni długich godzin pracy, pracy zmianowej, w nocy, niedziele i święta, a ich grafiki często pozostaja nieregularne i nieelastyczne. Dodatkowo intensywne kontakty z klientami o zróżnicowanych potrzebach i nierzadko dysfunkcjonalnych zachowaniach sprawiaja, że kontakty usługowe w hotelarstwie wymagają szczególnego wysiłku personelu, by za każdym razem świadczyć usługi na optymalnym, najwyższym poziomie. Sprostanie tym wyzwaniom wymaga od pracowników wyjątkowego zaangażowania, w tym poświęcenia ich czasu i energii, pozostawiajac w rezultacie mniej tych zasobów na realizację innych, pozazawodowych ról (w tym rodzinnych). Nie dziwi więc, że pracownicy branży hotelarskiej, starając się sprostać wysokim wymaganiom pracy, mogą być szczególnie narażeni na doświadczenie konfliktu między pracą a rodzina. co w rezultacie może mieć negatywny wpływ na ich postawy i zachowania, zwłaszcza względem klientów, prowadząc do obojętności względem ich potrzeb i problemów oraz obniżenia jakości świadczonych usług.

Cel badań. Celem niniejszych badań była próba identyfikacji zależności między konfliktem praca-rodzina i jego konsekwencjami dla procesu obsługi. Problemem badawczym było poszukiwanie odpowiedzi na pytania: 1. czy istnieje związek między konfliktem praca-rodzina a depersonalizacją pracowników, którą charakteryzuja m.in. cyniczne i obojętne postawy wobec innych, oraz 2. czy depersonalizacja może osłabić orientację pracowników na klienta i jego potrzeby oraz wysoki poziom ich obsługi, wychodząc ponad to, co jest od nich wymagane, by spełnić, a nawet przekroczyć oczekiwania gości.

Metodologia. Zastosowane metody badawcze opierają się na analizie źródeł wtórnych, w tym publikacji zwartych, artykułów i raportów z badań przeprowadzonych w omawianej problematyce oraz badaniach pierwotnych (badania ankietowe). Badania własne przeprowadzono wśród pracowników ośmiu hoteli zlokalizowanych w województwie pomorskim. Łacznie w badaniu uczestniczyło 130 pracowników bezpośredniego kontaktu z gościem.

Kluczowe wnioski. Rezultaty badań ukazują istotną i pozytywną zależność między doświadczaniem konfliktu praca-rodzina a depersonalizacją pracowników badanych hoteli, która w rezultacie osłabia ich orientację na klienta i obniża ich poziom obsługi, powodując, iż są oni mniej skłonni, by wyjść ponad to, co jest od nich wymagane, by dostarczyć gościom wyjątkowych doświadczeń usługowych.

Słowa kluczowe: pracownicy hotelu, konflikt praca-rodzina, depersonalizacja, orientacja na klienta, obsługa klienta. 